\title{
Educating for Informed Community Involvement
}

\author{
Robert G. Bringle and Kathryn Steinberg \\ 2010 \\ American Journal of Community Psychology \\ 46(3-4), 428-441
}

\begin{abstract}
Service learning, which integrates community service into coursework, provides a pedagogical intervention that can promote the civic growth of students in unique and powerful ways. Research is reviewed that documents the capacity of service learning to meet learning objectives associated with a conceptual framework that focuses on the knowledge, skills, and dispositions of a civic-minded college graduate. The outcomes of service learning should facilitate these students assuming influential roles in helping others become empowered, and thereby are important for enhancing the quality of life in communities. We also review research that focuses on the impact of service learning for community outcomes. Finally, we present implications for teaching community psychology, and recommendations for future research on service learning and community engagement.
\end{abstract}

\section{Keywords}

Service-learning Civic-minded graduate Curriculum development Engaged scholarship Campuscommunity partnerships Literature review

\section{Introduction}

One of the presumptions of a well-functioning, viable democracy is that citizens are wellinformed about community issues, they participate in various ways in contributing to work around those community issues, and the quality of life is improved as a result of their involvement (Wandersman and Florin 1999). Democratic life, then, depends on developing in young adults the inclinations to become involved in civic matters and the capacity to act efficaciously. How can the knowledge, skills, and dispositions for civic involvement be developed to engender a sense of community and empowerment?

Developing good citizens is not a new role for higher education, and Levine (2003) notes that there are numerous pedagogical approaches for civic learning (e.g., classroom instruction on civics, moderated discussions of current events, student governance, community activities, simulations). However, the emergence of service learning as a pedagogical strategy has heightened attention to the civic domain as a set of intentional educational objectives to be addressed seriously in higher education (Astin and Sax 1998; Battistoni 2002; Zlotkowski 1999). Bringle and Hatcher (1995, p. 222) define service learning as: 
a credit-bearing educational experience in which students (a) participate in an organized service activity that meets identified community needs and (b) reflect on the service activity in such a way as to gain further understanding of course content, a broader appreciation of the discipline, and an enhanced sense of personal values and civic responsibility.

Unlike other forms of community-based education (e.g., internship, co-operative education, see Angelique et al. 2002; Furco 1996), the phrase "civic responsibility" denotes that service learning has the civic education of students as an explicit goal. Thus, service learning is not only about "serving to learn," but also about "learning to serve" and being involved in communities in a variety of ways (e.g., through direct service, political involvement, grassroots organizations, nonprofit sector). Although "citizenship cannot be reduced to service” (Dionne and Drogosz 2003, p. 25), service learning needs to be appreciated and understood as a means for teaching toward civic education objectives. The case for service learning can be strengthened, then, by understanding its capacity to prepare students to assume a civic-minded disposition in their career and acquire the knowledge, skills, and dispositions to be active citizens in their communities. For as Cunningham (2006) notes:

One of [the] goals is the broad-based education of students to be effective and engaged citizens in our democratic society, and to be good citizens in our increasingly international world. Civic learning outcomes from higher education are difficult to document, but they are one of the most important social and civic contributions our colleges and universities provide to our society (p. 4).

This review focuses almost exclusively on research on service learning in higher education, though there is a parallel set of research findings for the K-12 setting (see Billig 2002). Research on service learning can focus on the outcomes for students, faculty, institutions, or community partners. Since most of the empirical work has centered on student outcomes, this article will focus primarily on this domain. We will also review the growing body of research on community impact of service learning. Empirical literatures on outcomes of service learning for faculty and institutions are still developing, but we will provide some recommendations for research in these areas.

\section{Conceptual Framework for Student Outcomes}

Altman (1996) proposed a new conceptual model for higher education which included three domains of knowledge: foundational (basic disciplines, liberal education), professional (practitioner skills), and socially responsive knowledge. The goals of education in socially responsive knowledge are to: (a) educate students in society’s problems; (b) provide experiences so that students could come to understand community issues first-hand; and (c) educate students so that they gain the experience and skills to act on social problems. Altman viewed service learning as providing experiences that contribute to the acquisition and development of socially responsive knowledge and civic-minded graduates. By linking community service to academic content, service learning courses provide opportunities for students to gain a more detailed understanding of issues in modern society, such as homelessness, environmental issues, 
illiteracy, juvenile delinquency, and health disparities. Altman's construct of socially responsive knowledge resonates with one of the public purposes of higher education, to produce graduates who can contribute to a democratic society.

Institutions of higher education are increasingly focused on infrastructure and programs that produce graduates who are civically-minded (Bringle et al. 1999a; Brukardt et al. 2004; Colby et al. 2003; Harkavy and Puckett 1994; Langseth and Plater 2004; Zlotkowski 1999). From the perspective of higher education, we are defining a civic-minded graduate to be a person who has completed a course of study (e.g., bachelor's degree), and has the capacity and desire to work with others to achieve the common good. "Civic-mindedness" refers to a person's inclination or disposition to be knowledgeable of and involved in the community, and to have a commitment to act upon a sense of responsibility as a member of that community. Thus, the concept refers to a person's orientation toward the community and other people in the community (as distinct from an internal or self orientation, family orientation, or a corporate/profit orientation). For our purposes, we are interested in student involvement in a local community, although this could also be expanded to include community at the state, regional, national, or global level (Bringle et al. in press; Plater et al. in press). The qualities of civic-mindedness are developed in higher education through curricular and co-curricular activities, such as service learning courses, internships, fieldwork, political involvement, and co-curricular voluntary service.

In order to explicate the construct of civic-minded graduate, we conducted an extensive literature review (detailed below), held conversations with informed scholars in the field, and reviewed measurement strategies on our campus and others (e.g., Tufts University, University of Maryland College Park). From this we compiled a comprehensive list of student learning outcomes that are important for a civic-minded graduate. Some scholars (e.g., Battistoni 2002; Welch 2007) had previously enumerated skills for engaged citizenship; these lists often overlapped (providing some consensus on content) but were limited to a particular discipline or approach. Our first aim was to compile a comprehensive list of student civic learning outcomes. Then we divided the list into core elements on which there appeared to be some consensus and which were applicable to a wide range of service learning courses and other civic education programs. This resulted in our conceptual framework for the construct of civic-minded graduate that is comprised of a set of students' knowledge outcomes (cognitive), dispositions (affective), skills, behavioral intentions, and behaviors. This includes seven elements that we have identified as the most central components to be manifested in a civic-minded graduate, and which can be fostered through undergraduate education that includes service learning. The core elements of the civic-minded graduate domain include:

(a) Academic Knowledge and Technical Skills: In receiving a college education, the civicminded graduate will have acquired advanced knowledge and skills in at least one discipline that are relevant to issues in the community.

(b) Knowledge of Volunteer Opportunities and Nonprofit Organizations: Civic-minded graduates will have a conception of the ways they can contribute to society, particularly through nonprofit organizations and volunteering.

(c) Knowledge of Contemporary Social Issues: Civic-minded graduates have an understanding of the complex issues encountered in modern society, both at the local and national levels. 
(d) Listening and Communication Skills: In order to help solve problems in society, civicminded graduates have the ability to communicate well with others. This includes written and spoken proficiency as well as the art of listening to divergent points of view.

(e) Diversity Skills: Civic-minded graduates have a rich understanding of, sensitivity to, and respect for human diversity in the pluralistic society in which they live. This can be fostered by students' interactions with persons in the community who are different from themselves in terms of racial, economic, religious, or other background characteristics.

(f) Self-Efficacy: Civic-minded graduates have a desire to take personal action, and also have a realistic view that the action will produce the desired results. Self-efficacy is a key component of personal empowerment.

(g) Behavioral Intentions $\rightarrow$ Civic Behavior: Behavioral intentions can be viewed as predictors of behaviors. Civic-minded graduates demonstrate that they value civic engagement by stating intentions to be involved in community service in the future and displaying forms of civic involvement. One of the clearest ways that students can manifest these attributes is by choosing a service-based career, or by manifesting civic dimensions to a career in any field.

There are many types of knowledge, skills, attitudes, and dispositions that are not included in this conceptual framework (e.g., leadership, teamwork, consensus-building, general problem-solving skills, knowledge of the community impact of service learning). We posit that these are implied by the delineated list, or are combinations of those identified in the list.

For example, knowledge of the impact of civic action in the community is strongly implied by the core elements of self-efficacy, knowledge of contemporary social issues, and knowledge of volunteer opportunities and nonprofit organizations. Self-efficacy may result from past accomplishments relevant to civic action (e.g., past service learning experiences that yielded a desired community impact), or past vicarious experiences (e.g., observation of other service learning projects leading to desired effects in the community). Moreover, knowledge of community impact is directly tied to knowledge of contemporary social issues, since the "expertise and cognitive capacity to make intelligent decisions about what needs to be done" (Eyler and Giles 1999, p. 159) must be based, at least in part, on one’s knowledge of past projects that have been successful for various community issues. Finally, knowledge of volunteer opportunities and nonprofit organizations requires one to be aware of the relative effectiveness of available projects and initiatives in the community that improve the quality of life in communities.

With regard to the core elements of the conceptual frameworks, other types of outcomes (e.g., moral development, belief in a just world, political involvement) are strengths of some, but not most service learning courses. These could be measured outcomes, when appropriate, but fail to be implicated in the breadth of service learning courses and are not included. Overall, these seven characteristics are good representatives for the goals associated with most, if not all, service learning courses (Eyler et al. 2001).

The conceptual domain of the civic-minded graduate will be used to organize a summary of the research findings that support service learning as a means for achieving the civic education of college students. The research evidence on outcomes of higher education service learning is 
small, but growing (see Billig and Eyler 2003). Unfortunately, many of the studies that do exist in the literature utilize one-shot case studies of single service learning courses or programs, sometimes with a post-test only design. Although this type of study may be useful for program evaluators or practitioners who are designing service learning courses, they have limited generalizability and typically do not contribute substantively to the research or theoretical knowledge base. This review, therefore, is not intended to be exhaustive, but focuses on what are typically the highest quality and most persuasive research studies that are currently available for particular content domains. In some cases, there are null findings or contradictory findings that may exist, but are not summarized because of the limitations of the research (e.g., small sample size, not controlling for extraneous variables or self-selection of students into classes).

\section{Academic Knowledge and Technical Skills}

Colleges and universities are, first and foremost, interested in developing the academic competencies of their students. Administrators who are expected to support service learning are most likely to ask about the degree to which service learning contributes to academic objectives, either within a course or more broadly across courses in the curriculum (e.g., general education, the major, the degree). Educational objectives may include both specific course content and cognitive skills such as critical thinking and problem solving that accumulate across courses. There are two fundamental types of questions that can be posed for service learning: (a) Do students learn the intended course objectives as a result of service learning? (b) Is service learning better than traditional pedagogies for achieving those objectives?

For the first question, one basis of comparison is how students change over time, preferably based on an independent judgment of student products (versus student self-reports of learning; see Steinke and Buresh 2002). For example, in a qualitative study, Ash et al. (2005) had independent raters apply rubrics to evaluate the quality of thinking demonstrated in students' reflection or other written products in two different service learning classes. They found that the rubrics could be used to give feedback to students, thereby improving critical thinking skills and higher order reasoning abilities (analysis, synthesis, and evaluation) in relation to academic learning, civic development, and personal growth areas. Furthermore, they found that these skills could be improved across writing drafts within one classroom session as well as across a semester. Shortcomings of this study are that it only involved two service learning courses and did not include non-service learning courses for comparison purposes.

The most persuasive evidence that service learning's contributions to academic outcomes are superior to traditional pedagogies comes from studies that have multiple sections, control for student self-selection into sections, provide a comparison to other pedadogies (e.g., traditional approaches to teaching the subject), and have an independent assessment of learning (vs. selfreports of perceived learning by students). Using a qualitative approach to the assessment of thinking skills, Eyler and Giles (1999) transcribed interviews of students who were asked to define a particular community problem, analyze the causes and potential solutions, and suggest strategies for change. Eyler and Giles controlled for age, previous service, gender, and scores on a similar exercise given at the beginning of the semester. Interview transcripts, scored by independent raters, indicated that service learning was related to gains in problem analysis complexity, solution complexity, knowledge application, and critical thinking ability. Students in 
programs with no service options, or with little linkage between service and curriculum, had significantly less change in scores than students in courses in which community service was integrated with course content.

Batchelder and Root (1994) used rubrics to evaluate written responses to social problems, comparing students in service learning courses to students in similar traditional courses. Although this study used a nonequivalent control group design, pre-course differences were statistically controlled through the use of hierarchical multiple regression analyses. Comparisons of pre- and post-course responses revealed significant gains for the service learning students on cognitive dimensions, such as awareness of the multidimensionality of social problems and their solutions.

In a quasi-experimental study, Markus et al. (1993) incorporated service learning into two of the eight sections of a large political science course. At the time of registration, students did not know which sections would be service learning and which would be taught traditionally with a research paper rather than a community service component. Although this is not random assignment of students to sections, it would produce equivalence of groups in the absence of differential dropout and if there were little or no movement of students between sections after the beginning of the course. Prior to the study there were no significant differences between students in service learning and traditional sections in terms of social and political beliefs and values. All sections had the same lectures and exams, and took a common final examination to assess mastery of course content. The students in the service learning sections demonstrated significantly better learning on the final exam than those students in the other sections. Students in service learning sections also achieved higher course grades, but this may have reflected the differential grading scheme of the sections.

Osborne et al. (1998) provide another example of comparing service learning's academic outcomes to traditional methods of instruction. Similar to Markus et al. (1993), Osborne et al. used a quasi-experimental design to study multiple sections of a communications course for pharmacy students. Students were not aware at the time of registration that some of the sections included a service learning component and some did not. Pretests indicated no significant differences between sections on scales measuring students' sense of self-worth, cognitive complexity development, social behavior, and sense of competence. Students in all sections produced written products during and at the end of the course that were assessed by independent raters for the degree to which they met four course objectives centered on communication issues: (a) complexity of communication; (b) integration of practical examples into communications; (c) sensitivity of communications; and (d) awareness of diversity. Compared to students in the traditional sections, students in the sections that included a community service component received higher ratings on their written products on all variables except complexity of communications.

In a natural quasi-experiment, Kendrick (1996) compared course exam scores in two sections of the same introductory sociology course in the same semester. One section included a service component whereas the other did not. Although students self-selected into the service section, Kendrick found no significant pre-test differences between students on demographic variables, prior or current service activities, or motivation indicators. Kendrick found that student 
performance in sections including service learning was better on essay examinations, but not multiple choice examinations, when compared to students in the traditional section. Kendrick suggests that this pattern indicates that "service-learning promotes quality of thought, even though it may not improve knowledge content” (p. 79). A similar finding was reported by Stage (2000). A limitation of the Kendrick study is that the author conducted all student grading, introducing potential researcher bias into how the essay exams were graded.

Reeb et al. (1999) report that service learning students achieved superior academic performance on essay/multiple-choice exams, relative to traditional students in an abnormal psychology course. In this quasi-experiment, students who chose to participate in service learning received an extra credit hour in the course, but all students completed the same exams as part of their course grade. Although service learning and traditional students achieved similar scores on the first exam, as the semester progressed service learning students showed increasingly superior academic performance compared to the non-service students. Service learning students also gave higher ratings on a post-semester course evaluation on level of learning, ability to apply course concepts to new situations, interest and motivation, personal development, and quality of the instructor.

There are only a few studies that have examined the role of service learning contributing to academic outcomes across the curriculum, rather than as the result of a particular course. Vogelgesang and Astin (2000) conducted secondary analysis of data collected in a large national study by the UCLA Higher Education Research Institute. In this longitudinal study, students from a variety of institutions completed a self-report survey in their first year and a similar survey 4 years later. Vogelgesang and Astin relied on the self-report measures of academic outcomes (GPA, growth in writing skills, critical thinking skills) to compare students who had service learning course experiences to students who had participated in other forms of community service. After controlling for characteristics of students when entering college, college size, and college type, the results indicated that both co-curricular community service and service learning were associated with higher academic outcomes, but service learning had a larger degree of association and it was independent of participation in co-curricular community service. Although these results were based on students' self-report, Jameson et al. (2008) found similar results based on independent assessment of student products from multiple courses in a Nonprofit minor. In this study student learning in later courses was more advanced on Bloom's Taxonomy than student learning in earlier courses.

\section{Knowledge of Volunteer Opportunities and Nonprofit Organizations}

Colleges and universities are becoming increasingly aware of their responsibilities as citizens in the context of the communities in which they reside. Campuses are intentionally increasing programs to be involved in local communities in ways that go beyond the direct, classroombased education of students (Campus Compact 2007). Colleges and universities also seek to strengthen the communities themselves and empower the nonprofit sector as an important element of those communities (Bringle et al. 1999b). One of the consequences of intentional community involvement through college courses and civic education programs is to provide opportunities for students to develop knowledge of volunteer opportunities in the community. Students also gain valuable exposure to, and knowledge of, the nonprofit organizations that are 
involved in many campus-community partnerships. Students involved in either curricular (service learning) or co-curricular service activities have opportunities to learn about the particular organization(s) with which they are involved, the clientele that are served, and the types of service opportunities that are available. Service learning courses also provide avenues for students to learn about particular agencies (many of which are nonprofit organizations) what they do, how they are organized, the problems they face, the clientele they serve, and some of the ways they address social problems in society. A key component, then, of the civic-minded graduate, regardless of career path, is knowledge of opportunities for community service, particularly through the nonprofit sector.

Little research attention has been devoted to the question of whether community involvement among undergraduates results in student knowledge of volunteer opportunities and the nonprofit sector. In the quasi-experimental study described earlier, Markus et al. (1993) reported that service learning students attached increased importance to volunteering, whereas the attitudes of non-service learning students did not change over the course of a semester. Bringle et al. (2006) took yet another approach to the problem of student self-selection by purposefully surveying college students who had been involved in community service or volunteer activities. They used a self-report measure to study student interest in three service paradigms identified by Morton (1995): charity (providing direct service to another person), project (implementing or participating in service programs through community service organizations), and social change (transformational models of systemic change). Student interest in each of these was correlated with interest in and knowledge of the nonprofit sector (e.g., had enrolled in a course that included the nonprofit sector; familiarity with the nonprofit sector; interest in taking a course on the nonprofit sector; interest in employment in the nonprofit sector). This suggests that the curriculum should place additional emphasis on the nonprofit sector's role in community involvement and that student involvement can benefit from educational programs that are designed to increase their knowledge of the nonprofit sector (e.g., philanthropic studies, nonprofit management). Service learning instructors can intentionally draw upon the knowledge base about the nonprofit sector (Anheier 2005; Clotfelter and Erhlich 1999; Hammack 1998; Powell 1987) to supplement existing course content so that students can deepen their understanding of the role of nonprofits in society, and the relationships of the nonprofit sector to the public/government sector and the private/for-profit sector in addressing community needs.

Another dimension of students' growth related to community involvement is the degree to which service learning contributes to a sense of community (Fisher et al. 2002). "The idea that we belong to communities and that these communities provide benefits and responsibilities is one that has gained a growing appreciation in the last decade” (Bess et al. 2002, p. 3). Warchal and Ruiz (2004) administered a self-report survey to four cohorts of alumni from a small religious institution; different cohorts had different requirements for community service and/or service learning courses. The researchers found that students' involvement in service learning during college was positively correlated with: the likelihood that students were offered a job at the service placement site; their first job and current job being in the same state as their service placement; acceptance of employment in service-related fields; and the likelihood and amount of post-graduation community service. This study is limited by possible cohort effects and because results may not generalize beyond their institution. 


\section{Knowledge of Contemporary Social Issues}

According to Eyler and Giles (1999), one of the key dimensions of citizenship is knowledge of what one should do and why-the "expertise and cognitive capacity to make intelligent decisions about what needs to be done" (p. 159), which includes understanding social issues and programs. Eyler and Giles posit that student intellectual development is related to their understanding of complex social problems. For example, Driscoll et al. (1996) used a multi-method approach to measure the impact of four service learning courses on students, faculty, institutions, and community agencies. Student measures included pre-post course surveys, interviews, focus groups, journal analysis, and classroom observation. They found that service learning affected student awareness of and involvement with the community, including its history, strengths, and problems. This is one of the few studies in the service learning research literature that employs multiple methods to examine converging results.

In a national study of students from 42 institutions, Astin and Sax (1998) conducted secondary analysis of data from the Cooperative Institutional Research Program (CIRP) Freshman Survey, SAT and ACT scores, and enrollment data for entering college students in five cohorts from 1990 to 1994. They also administered follow-up surveys to students in 1995. After controlling statistically for confounding first-year student characteristics (e.g., propensity for service) and institutional variables (e.g., size), all 35 student outcome measures were favorably related to service participation in college. In particular, service learning pedagogy was associated with increased student understanding of the problems faced by the community and the nation as a whole, for all sectors in which service was provided (education, human services, public safety, and environment). As with many studies in the service learning literature, the outcome measures related to civic responsibility in this study were all based on students' self-reports.

\section{Listening and Communication Skills}

Sullivan (1988, 2004, 2005) has renewed the call of John Dewey, Jane Addams, and others for universities to educate students toward "civic professionalism." In Sullivan's view, the civicminded professional embarks on a career with a public-service orientation in mind, rather than a solely technical or economic/profit orientation to practice. According to Sullivan, the civicminded professional has a variety of skills in addition to professional knowledge and skills; among these skills is the ability to communicate well with others, and especially the ability to listen to divergent points of view.

Communication skills are among the set of personal resources (along with time and money) that have been proposed as necessary for political participation (Brady et al. 1995). This includes spoken proficiency, vocabulary, writing letters, and giving a presentation or speech. Battistoni (1997) described communication skills as an essential component of a civically-oriented service learning program. According to Battistoni, education for democratic citizenship includes not only speech, argument, and persuasive writing, but equally important, listening skills. "In a democracy, citizens need to be able to listen to each other, understand the places and interests of others in the community, and achieve compromises and solve problems when conflict occurs” (p. 153). Service learning courses provide opportunities for students to develop written and oral communication skills, as well the art of listening, through service in community settings and 
reflection strategies in the classroom. Service learning researchers in general agree that communication skills are important for engaged citizens, and some (e.g., Eyler and Giles 1999; Moely et al. 2002) have included listening and general interpersonal skills in scales or subscales that assess skills that are useful in civic endeavors.

We are not aware of any empirical research that specifically investigates student listening skills as outcomes of service learning. This, then, is an area that is ripe for future research. Osborne et al. (1998) did provide an example of service learning enhancing written communication skills. In this study, described earlier, students in the service learning sections produced higher quality written products on all measured communication variables, except complexity of communications, than those students in the traditional sections.

In a quasi-experimental study, Tucker and McCarthy (2001) investigated the impact of service learning on students' self-perceived presentation skills, using pre-post surveys of students enrolled in service learning business courses compared to students in non-service business courses. The surveys asked students to rate their confidence in their ability to make presentations of business concepts to groups of elementary children, college peers, and adults. Hierarchical regression was used to control statistically for self-selection into service learning courses and pre-test self-efficacy scores. Post-test results showed that participation in service learning courses was significantly related to students' confidence in their ability to make presentations to children, college peers, and adults. In addition, service learning students who had low pre-test scores also reported an increase in presentation self-confidence for each audience. This study would have benefited from having objective ratings of student presentations, to corroborate the results from the self-report measures.

\section{Diversity Skills}

Institutions of higher education are increasingly addressing issues of diversity in response to an American society that is becoming ever more pluralistic, including integrating diversity issues into their mission statements, administrative structures, curricular offerings, and student and faculty recruitment and retention efforts. "Education for democracy in. . . America means education for participation in an increasingly diverse world” (Battistoni 1995, p. 34). Service learning is seen as a pedagogy that makes diversity issues particularly salient to students by placing them in community environments in which they interact with persons who are different from themselves in terms of racial, economic, religious, or other background characteristics.

Research studies have documented that service learning has an impact on student perceptions, values, and behaviors related to diversity. Many of these studies utilize student self-reports on surveys to document that service learning is associated with improved diversity skills. For example, service learning has been found to: increase student sensitivity to diversity (Driscoll et al. 1996); increase student knowledge of, and ability to get along with, people of different races and cultures (Astin and Sax 1998); increase student tolerance and decrease the application of stereotypes and social stigma (Eyler and Giles 1999; Eyler et al. 1997); and increase students' ability to work with diverse groups (Osborne et al. 1998). Being involved in service learning courses during college predicted students' ability to put themselves in someone else's shoes, regardless of their background (Eyler et al. 1997). Two studies (Astin and Sax 1998; 
Vogelgesang and Astin 2000) found that service learning experiences were related to student commitment to promoting racial understanding. Finally, Astin et al. (1999) conducted a longitudinal survey study and found that the frequency of volunteering during the last year of college was positively correlated with reported promotion of racial understanding 9 years after graduation.

Two quasi-experimental nonequivalent control group studies examined the effects of service learning on students' intercultural sensitivity. Fitch (2004) reported on a study in which students chose to enroll in one of four kinds of courses: service learning only (no cultural course content); cultural content only (no service learning); cultural content plus service learning; and courses with neither cultural content nor service learning. All service learning experiences were designed to include intercultural contact. Regression analyses indicated that the type of course was a significant predictor of levels of intercultural sensitivity. Further, the group that enrolled in courses with both cultural content and service learning had the highest percentages of students who moved from a dualistic view to a relativistic view of intercultural differences.

Myers-Lipton (1996) investigated a program in which students performed at least 6 hours of service per week, integrated into four courses over the 2-year program. The study involved two nonequivalent control groups (students who performed co-curricular volunteer service, and a random group of students not involved in service). After controlling for pre-test differences between groups, regression analyses showed that service learning students had larger reductions in modern racism than students in the control groups. Myers-Lipton noted that a threat to the internal validity of this study came from differential mortality rates between the service learning and control groups.

In a qualitative study that involved interviews, observations, and reflective essays from students and service site directors, Boyle-Baise (2002) studied how pre-service teachers made meaning of their multicultural service learning experiences. Results indicated that all of the 24 pre-service teachers shifted their perceptions of the children with whom they worked from deficit views to a focus on commonalities. In addition the pre-service teachers of color, and the white students who had prior experience living in diverse settings, developed even more nuanced perspectives and did not gloss over differences between social and economic circumstances.

\section{Self-Efficacy}

Inherent in the propensity to take civic action (i.e., to be empowered) is a cluster of interrelated constructs dealing with cognitions, motivations, and attitudes that focus on efficacy, control, and achievement. Self-efficacy as a goal of civic education captures the tendency of the individual to be inclined to take action, to expect that the action will produce the desired result, and learning from actions by self and other. According to Bandura (1997), "self-efficacy is a judgment of one’s ability to organize and execute given types of performances” (p. 21).

Efficacy, and the related elements of perceived control and competency, are viewed as key components of personal empowerment and have been found to discriminate between high participation groups versus groups with low or no participation (Zimmerman and Rappaport 
1988). Furthermore, Balcazar et al. (1990) have demonstrated that community interventions can increase perceptions of control.

Williams et al. (2002) found that self-efficacy scores, based on core competencies of professional social workers, increased during a service learning course for social work M.S. students. The students completed a pre- and post-semester survey based on Bandura's (1997) model of self-efficacy. The findings indicated a statistically significant increase in general selfefficacy and self-efficacy related to mezzo- and macro-level skills. Limitations of this study include its single group pretest-posttest design, the single self-report measure that was used, and the lack of controls for student self-selection into the course.

Reeb et al. (1998) developed a Community Service Self-Efficacy Scale (CSSES) to measure "the student's confidence in his or her own ability to make clinically significant contributions to the community through service” (p. 49). Students who engaged in service reported higher scores on this instrument than did less engaged students. Reeb (2006) conducted further validation studies and found that the CSSES could be used with adolescents as well as a college population. The article by Reeb and colleagues in this volume provides further discussion of the role and measurement of self-efficacy as an outcome variable, mediating variable, and moderating variable in service learning research and practice.

Eyler et al. (1997) gathered self-report survey data from students at 20 colleges and universities. Pre- and post-semester surveys were collected from more than 1,100 students involved in courses with a service component, and from over 400 students who selected non-service courses. Group equivalence was achieved through statistical controls for rival hypotheses to the impact of service learning (pretest differences in gender, race, parental income, age, and students' previous college volunteer experience). The researchers found that participation in service learning increased students' belief that they could be personally effective in their community.

\section{Behavioral Intentions $\rightarrow$ Behavior}

The Theory of Reasoned Action (TRA) (Ajzen and Fishbein 1980; Fishbein and Ajzen 1975) and the Theory of Planned Behavior (TPB) (Ajzen 1985, 1991) both provide a basis for understanding the relationship between behavioral intentions and behaviors. In both theories, behavioral intentions are viewed as predictors of behaviors. The TRA predicts that behavioral intentions are a function of attitudes toward the behavior and subjective norms associated with the behaviors; the TPB adds behavioral control as a predictor of behavioral intentions. One implication of these theories is the posited relationships among attitudes, beliefs (a component of attitudes), norms, the perceived capacity to take action (i.e., control), and behavioral intentions. Although the strength of the bivariate relationships can vary, there are theoretical reasons for expecting relationships. The relationships between and among these constructs is one of the reasons that they are sometimes clustered in measures. For example, the Civic Attitudes and Skills Questionnaire (CASQ) developed by Moely et al. (2002) contains items that measure: behavioral intentions to be involved in community service in the future (e.g., "I plan to do volunteer work"); beliefs about skills and competencies (e.g., "I can listen to other people's opinions"); and attitudes (e.g., about social justice, diversity: "I enjoy meeting people who come from backgrounds very different from my own”). Not unexpectedly, there are moderate 
correlations between the subsets of items on the CASQ (Moely et al. 2002). Other scales focused on measuring the results of service learning courses also contain a mixture of behavioral intentions and other components (see Bringle et al. 2004).

Although most research on the outcomes of service learning focuses on variables measured at the end of a course, or at the end of studies, there may also be lagged effects that occur for students. Are service learning experiences during college related to later behaviors after graduation? Subsequent student behavior might reflect changes in attitudes, values, and dispositions that are associated with the "learning to serve" objective of service learning. Several studies indicate service learning during the high school and college years is associated with increased likelihood of community service after graduation. For example, Astin et al. (1999) studied whether service participation during the undergraduate years had any effects on students after leaving school. In this national longitudinal study, students completed a self-report survey when they entered college, again 4 years later, and then again 5 years after graduation. The final sample included over 12,000 students from 209 institutions that had data from all three surveys. After controlling statistically for freshman scores on behavioral and attitudinal variables, the researchers found that the amount of reported volunteering during high school correlated with the frequency of volunteering after college graduation. Furthermore, students who spent at least 6 hours a week in volunteer service during their last year of college were almost twice as likely to volunteer after college. Volunteering during college was also associated with the following outcome behaviors and values: frequency of socializing with diverse people, promoting racial understanding, helping others in difficulty, participating in community action programs and environmental cleanup, developing a meaningful life philosophy, a sense of efficacy, and hours spent volunteering after college. One limitation of this study is that the independent variable was the simple number of volunteer hours contributed during the senior year; the investigators did not obtain specific information about curricular (service learning) versus co-curricular experiences, types of service performed, or the types of community agencies involved in the service.

At a broader level, students might manifest the effects of service learning in other behavioral choices that they make after graduation. Sullivan (2005) delineates the dimensions of what it means to be a civically-oriented professional beyond the technical competence and knowledge expertise that professional education typically emphasizes:

To become a professional is not only to join an occupation; it is to assume a civic identity. The core of professionalism is that by functioning as lawyer, engineer, doctor, accountant, architect, teacher, or nurse, an individual carries on a public understanding and affirms public values. With this identity comes a certain public status and authority. . . but professionalism also means duties to the public. Chief among these duties is the demand that a professional work in such a way that the outcome of the work contributes to the public value for which the profession stands (p. 23).

Sullivan's (2005) analysis emphasizes how civic-minded professionals can become social trustees in a manner that encompasses a sense of social responsibility for career choices. One of the clearest ways in which students can manifest these attributes is by choosing a career in the nonprofit service sector, or by manifesting civic dimensions to a career in any field. In making these choices, students are clearly demonstrating that they value civic engagement. 
Vogelgesang and Astin (2000) found that service learning during college was associated with choosing a career that was focused on service at the end of college, after controlling for prior experience with voluntary service. As they note, because a career choice encompasses commitment to a set of values, service learning's effect on choosing a service-based career is very significant and consistent with the expectation that service learning reflects the students' involvement in the nonprofit sector. Fenzel and Peyrot (2005) replicated this result for alumni interviewed up to 6 years post-graduation.

\section{Community Outcomes}

Service learning focuses attention on both its contributions to the quality of life in communities (e.g., literacy rates) and the partnerships that develop with the community. Clayton et al. (2008) have developed a conceptual framework to analyze the relationships in service learning (e.g., between faculty, students, administrators, residents, staff at community organizations) as the unit of analysis and the degree to which the relationships are exploitative, transactional, or transformative. Thus, although student outcomes are important to the academy, well-designed service learning courses also focus on how student and faculty involvement benefits the communities and the partner organizations that host service learning students. Students who participate in service learning projects that make a significant community contribution may be more likely to have an even stronger sense of self-efficacy and a commitment for future service. Community agencies may view these students as potential future volunteers, advocates, or even employees. In addition, community organizations that host successful service learning projects often report anecdotally that such projects help them to: implement their mission, meet community needs that would otherwise go unmet, enhance or increase the services offered, increase the number of clients served, increase their ability to leverage funding or other resources, and form new connections with the university or other agencies (Sandy and Holland 2006). Assessing the impact on community partners is a vital component of evaluating service learning courses and programs, because "effective and sustainable service-learning depends on mutually-beneficial partnerships between campus and community” (Gelmon et al. 2001, p. 83).

Only a few empirical research studies have focused on the impact of service learning from the perspective of the community partner (e.g., residents, clients, organizations). Driscoll et al. (1996) presented a case study of impact assessment for four service learning courses at Portland State University. They utilized both quantitative and qualitative measures, including surveys, interviews, and focus groups with community partners. Community agencies perceived that hosting service learning students had a positive impact on their capacity to serve clients, led to improved social and economic benefits for the agencies, and provided new insights about program operations.

Sandy and Holland (2006) conducted a qualitative study using focus groups with 99 community partners of eight California campuses and found that the partnership relationship itself was valued as the highest priority among all groups. The community agencies also identified ways in which service learning students contributed to client outcomes (e.g., role modeling for youth, companionship for the elderly), and enhanced organizational capacity to take on new projects. In addition, partners commented on the opportunities for staff and organizational enrichment and development that resulted from hosting service learning students. The agencies in this study 
uniformly expressed a commitment to student learning as an important reason for their involvement in service learning. A limitation of this study is that the authors did not include community partners who were not involved with service learning students.

Although hosting service learning students may have negative consequences as well as positive ones (Gazley and Littlepage 2006), most research indicates that community partners feel that the benefits of working with student volunteers far outweighs the costs (Gazley and Littlepage 2006; Gray et al. 1999). In a survey of 267 community respondents working with 13 campuses, Bringle and Hatcher (2006) found that community respondents were overwhelmingly positive (>90\%) on the benefits of different kinds of community involvement by campuses (e.g., tutoring programs, service learning, volunteers). In addition, they reported that they thought that the university had been significantly more involved in community decisions than the community had been in university decisions.

\section{Implications for Teaching Community Psychology}

Service learning can be considered a powerful pedagogy because of the degree to which it aligns with what is known to foster depth of understanding: (a) active learning; (b) frequent feedback from others (e.g., faculty, service learning coordinator, students, service providers) that is provided in non-threatening ways; (c) collaboration with others; (d) cognitive apprenticeship (i.e., a mentor with whom students can discuss and learn generalization of principles, transfer of knowledge between theory and practice, ability to analyze perplexing circumstances); and (e) practical application in which students are involved in tasks that have real consequences but have a safety net for high stakes mistakes (Marchese 1997). Furthermore, service learning has demonstrated the capacity to foster the civic growth of college students on numerous dimensions that prepare them for an active civic life. Interestingly, in a recent review of course syllabi, Carmony et al. (2000) found that only $42 \%$ of undergraduate community psychology courses included a service or field component, despite the relevance of service learning as a pedagogical tool for these courses.

Many university-based community psychology programs include courses on action research. Frequently these courses utilize students as research assistants, and some courses combine action research and service learning experiences. For example, Nigro and Wortham (1998) described an action research course in which service learning students assisted community agencies with surveys. Some of the projects included: a child abuse prevention agency that surveyed all schools in the county about levels of violence and efforts in violence prevention; a youth agency that wished to know if its transitional living program increased protective factors for its clients; and a youth agency that was interested in the experiences of female juvenile offenders pre- and postan after-care program. Such experiences offer benefits to the students, the educational institution, and the community partner alike.

\section{Recommendations for Future Service Learning Research}

Although the use of service learning as pedagogy in higher education classes has blossomed over the past 20 years, there is an acute need for high quality research on service learning outcomes across institutions, faculty, students, and communities (Bringle and Hatcher 2000). There is 
consensus (Bringle 2003; Bringle et al. 2004; Gelmon et al. 2005) that good research on service learning should:

- Be guided by theory. All research, whether quantitative or qualitative in nature, should be guided by a theoretical framework and be based on and contribute to the existing knowledge base in the field.

- Involve clearly defined constructs. Many studies do not clearly outline the experiences being defined as service learning (Billig and Eyler 2003). In addition to defining the independent and dependent variables, researchers also need to identify and explore the role of important moderator variables (such as type of community organization, size and type of college) and mediating variables (e.g., self-efficacy, civic-mindedness) (Bringle 2003).

- Control for, or account for, differences among groups. Researchers should use scientific research design (e.g., experimental method, analysis of covariance to control for preexisting differences) to control for extraneous explanations and allow causal inferences (see Bringle and Hatcher 2000). Self-selection of participants into service learning courses creates the problem of non-random assignment of students to a service learning group versus a non-service learning group.

- Use psychometrically defensible measures that have multiple indicators. Service learning research measurement procedures should possess demonstrable reliability and validity (Bringle et al. 2004). Because constructs such as civic-mindedness and social responsibility are "socially desirable" attributes, researchers need to counteract socialdesirability response bias in measures by including neutral or negatively-worded items in survey or interview protocols or writing items in ways that control for the bias. Most service learning research that involves student measures utilizes tools that are based on student testimony or self-report, which presents a number of problems (see Bringle et al. 2004; Steinke and Buresh 2002). Researchers should consider using other measurement procedures, such as behavioral ratings by an external observer and independent coding of student products.

- Use multiple methods if possible, and establish converging results across different methods. Incorporating multiple measures and multiple methods allows triangulation of converging results to increase understanding, confidence, and generalizability.

- Use designs that result in confidence in the conclusions that are reached. Many service learning studies do not include adequate control or comparison groups that contrast the intervention with other interventions in ways that would permit appropriate conclusions. Service learning research is plagued by small sample size or limited data, such as basing the research on a single course experience measured only at the end of a semester. We recommend that researchers avoid conducting a single case study with limited data; cross-case analysis can help to increase understanding and generalizability.

- Have implications for teaching and learning in general. Limitations of generalizability can apply to many aspects of the research (e.g., sampling, nature of the intervention, context-specific elements, measurement procedures). However, service learning as an engaging and active pedagogy may have implications for all teaching and learning (e.g., cognitive processes, student-centered instruction, collaborative learning). As assessment of instruction becomes more outcome oriented, there will be opportunities to assess how 
different pedagogical approaches, including service learning, contribute to achieving many desired learning outcomes.

Despite its limitations, the overall body of research supports the conclusion that service learning can lead to more civically-minded students who have increased post-graduation civic involvement. The outcomes of service learning should facilitate these students assuming influential roles in helping others become empowered, and thereby are important for enhancing the quality of life in communities.

As service learning continues to become more institutionalized, it presents interesting opportunities for research and scholarship on teaching and learning. Future research will need to improve on past research with longitudinal studies, multi-course studies, multi-campus studies, greater control on confounding variables, and more precise and authentic measurement of outcomes (e.g., student learning, retention). More complex research may warrant new networks of researchers, sharing databases for secondary data analyses, more concerted activities to gather cross-disciplinary teams to design large-scale studies, and linking different data sets (e.g., institutional research data, transcripts, alumni surveys) to service learning courses (Bringle and Hatcher in press). Future research can also link faculty development activities to curricular change to determine how they influence student learning and eventually community outcomes and partnerships. Studying these connections produces an additional area of research on how institutional support and infrastructure for service learning results in improved capacity for these constituencies to benefit. 


\section{References}

Ajzen, I. (1985). From intentions to actions: A theory of planned behavior. In J. Kuhl \& J. Beckmann (Eds.), Springer series in social psychology (pp. 11-39). Berlin: Springer.

Ajzen, I. (1991). The theory of planned behavior. Organizational Behavior and Human Decision Processes, 50(2), 179-211.

Ajzen, I., \& Fishbein, M. (1980). Understanding attitudes and predicting social behavior. Englewood Cliffs, NJ: Prentice-Hall.

Altman, I. (1996). Higher education and psychology in the millennium. American Psychologist, 51, 371-378.

Angelique, H. L., Reischl, T. L., \& Davidson, W. S. (2002). Promoting political empowerment: Evaluation of an intervention with university students. American Journal of Community Psychology, 30, 815-835.

Anheier, H. K. (2005). The nonprofit sector: Approaches, management, policy. London and New York: Routledge.

Ash, A. L., Clayton, P. H., \& Atkinson, M. P. (2005). Integrating reflection and assessment to capture and improve student learning. Michigan Journal of Community Service Learning, 11(2), 49-60.

Astin, A. W., \& Sax, L. J. (1998). How undergraduates are affected by service participation. Journal of College Student Development, 39, 251-263.

Astin, A. W., Sax, L. J., \& Avalos, J. (1999). The long-term effects of volunteerism during the undergraduate years. Review of Higher Education, 22(2), 187-202.

Balcazar, F. E., Seekins, T., Fawcett, S. B., \& Hopkins, B. L. (1990). Empowering people with physical disabilities through advocacy skills training. American Journal of Community Psychology, 18, 281-296.

Bandura, A. (1997). Self-efficacy: The exercise of control. New York: W. H. Freeman \& Co. Batchelder, T. H., \& Root, S. (1994). Effects of an undergraduate program to integrate academic learning and service: Cognitive, prosocial cognitive, and identity outcomes. Journal of Adolescence, 17, 341-355.

Battistoni, R. M. (1995). Service learning, diversity, and the liberal arts curriculum. Liberal Education, 81(1), 30-36.

Battistoni, R. M. (1997). Service learning and democratic citizenship. Theory into Practice, 36, 150-160.

Battistoni, R. M. (2002). Civic engagement across the curriculum: A resource book for servicelearning faculty in all disciplines. Providence, RI: Campus Compact.

Bess, K. D. D., Adrian, T. F., Sonn, C. C., \& Bishop, B. J. (2002). Psychological sense of community: Theory, research, and application. In A. T. Fisher, C. C. Sonn, \& B. J. Bishop (Eds.), Psychological sense of community: Research, applications, and implications (pp. 3-22). New York: Kluwer/Plenum.

Billig, S. H. (2002). Adoption, implementation, and sustainability of K-12 service-learning. In A. Furco \& S. H. Billig (Eds.), Service-learning: The essence of the pedagogy (pp. 245-267).

Greenwich, CT: Information Age.

Billig, S. H., \& Eyler, J. (2003). The state of service-learning and service-learning research. In S. H. Billig \& J. Eyler (Eds.), Deconstructing service-learning: Research exploring context, participation, and impacts (pp. 253-264). Greenwich, CT: Information Age. 
Boyle-Baise, M. (2002). Multicultural service learning: Educating teachers in diverse communities. New York: Teachers College Press.

Brady, H., Verba, S., \& Schlozman, K. (1995). Beyond SES: A resource model of political participation. American Political Science Review, 89, 271-294.

Bringle, R. G. (2003). Enhancing theory-based research on service-learning. In S. H. Billig \& J. Eyler (Eds.), Deconstructing service-learning: Research exploring context, participation, and impacts (pp. 3-21). Greenwich, CN: Information Age Publishing.

Bringle, R. G., Games, R., \& Malloy, E. A. (Eds.). (1999a). Colleges and universities as citizens. Needham Heights, MA: Allyn \& Bacon.

Bringle, R. G., Games, R., \& Malloy, E. A. (1999b). Colleges and universities as citizens: Reflections. In R. Bringle, R. Games, \& E. A. Malloy (Eds.), Colleges and universities as citizens (pp. 193-204). Needham Heights, MA: Allyn \& Bacon.

Bringle, R. G., \& Hatcher, J. A. (1995). A service-learning curriculum for faculty. Michigan Journal of Community Service Learning, 2, 112-122.

Bringle, R. G., \& Hatcher, J. A. (2000, Fall). Meaningful measurement of theory-based service learning outcomes. Michigan Journal of Community Service Learning, 68-75.

Bringle, R. G., \& Hatcher, J. A. (2006, October). Where's the community impact in servicelearning research. Paper presented at the 6th annual international conference on service-learning research, Portland, OR.

Bringle, R. G., \& Hatcher, J. A. (in press). Student engagement trends over time. In H. E. Fitzgerald, C. Burack, \& S. Seifer (Eds.), Handbook of engaged scholarship: The contemporary landscape (Vol. 2). Community-campus partnerships. East Lansing, MI: Michigan State University Press.

Bringle, R. G., Hatcher, J. A., \& Jones, S. G. (Eds.) (in press). International service learning: Conceptual frameworks and research. Sterling, VA: Stylus.

Bringle, R. G., Hatcher, J. A., \& McIntosh, R. (2006). Analyzing Morton’s typology of service paradigms and integrity. Michigan Journal of Community Service Learning, 13(1), 5-15. Bringle, R. G., Phillips, M., \& Hudson, M. (2004). The measure of service learning: Research scales to assess student experiences. Washington, DC: American Psychological Association. Brukardt, M. J., Holland, B., Percy, S. L., \& Zimpher, N. (2004). Calling the question: Is higher education ready to commit to community engagement? A wingspread statement. Milwaukee, WI: Milwaukee Idea Office, University of Wisconsin-Milwaukee.

Campus Compact. (2007). Campus Compact annual membership survey, 2006. Providence, RI: Campus Compact.

Carmony, T. M., Lock, T. L., Crabtree, A. K., Keller, J., Szeto, A., Yanasak, B., et al. (2000). Teaching community psychology: A brief review of undergraduate courses. Teaching of Psychology, 27, 214-216.

Clayton, P., Bringle, R. G., Huq, J., \& Cobb, T. (2008, October). Beyond reciprocity:

Investigating transactional vs. transformative dimensions of service-learning partnerships. Paper presented at the 8th annual international conference on service-learning research and community engagement, New Orleans, LA.

Clotfelter, C., \& Erhlich, T. (Eds.). (1999). Philanthropy and the nonprofit sector in a changing America. Bloomington and Indianapolis, IN: Indiana University Press.

Colby, A., Ehrlich, T., Beaumont, E., \& Stephens, J. (2003). Educating citizens: Preparing America's undergraduates for lives of moral and civic responsibility. San Francisco: JosseyBass. 
Cunningham, A. (2006). The broader societal benefits of higher education. Retrieved June 28, 2007, from

http://www.solutionsforourfuture.org/site/PageServer?pagename=societal_benefits_of_higher_ed ucation.

Dionne, E. J., Jr., \& Drogosz, K. M. (2003, Winter). United we serve: The debate over national service. Campus Compact Reader, 23-26.

Driscoll, A., Holland, B., Gelmon, S., \& Kerrigan, S. (1996). An assessment model for servicelearning: Comprehensive case studies of impact on faculty, students, community, and institutions. Michigan Journal of Community Service Learning, 3, 66-71.

Eyler, J., \& Giles, D. E., Jr. (1999). Where's the learning in service-learning?. San Francisco: Jossey-Bass.

Eyler, J. S., Giles, D. E., Jr., \& Braxton, J. (1997). The impact of service-learning on college students. Michigan Journal of Community Service Learning, 4, 5-15.

Eyler, J. S., Giles, D. E., Jr., Stenson, C. M., \& Gray, C. J. (2001). At a glance: What we know about the effects of service learning on college students, faculty, institutions and communities, 1993-2000 (3rd ed.). Washington, DC: Learn and Serve America, National Service Learning Clearinghouse.

Fenzel, L. M., \& Peyrot, M. (2005). Comparing college community participation and future service behaviors and attitudes. Michigan Journal of Community Service Learning, 12(1), 23-31. Fishbein, M., \& Ajzen, I. (1975). Belief, attitude, intention, and behavior: An introduction to theory and research. Reading, MA: Addison-Wesley.

Fisher, A. T., Sonn, C. C., \& Bishop, B. J. (Eds.). (2002). Psychological sense of community: Research, applications, and implications. New York: Kluwer/Plenum.

Fitch, P. (2004). Effects of intercultural service-learning experiences on intellectual development and intercultural sensitivity. In M. Welch \& S. H. Billig (Eds.), New perspectives in servicelearning: Research to advance the field (pp. 107-126). Greenwich, CT: Information Age. Furco, A. (1996). Service-learning: A balanced approach to experiential education. In Corporation for National Service (Ed.), Expanding boundaries: Serving and learning (pp. 2-6). Columbia, MD: The Cooperative Education Association.

Gazley, B., \& Littlepage, L. (2006, November). Understanding service-learning from a volunteer management capacity perspective. Paper presented at the annual meeting of the association for research on nonprofit organizations and voluntary action, Chicago, IL.

Gelmon, S., Furco, A., Holland, B., \& Bringle, R. G. (2005, November). Beyond anecdote: Challenges in bringing rigor to service-learning research. Paper presented at the 5th annual international K-H service-learning research conference, East Lansing, MI.

Gelmon, S. B., Holland, B., Driscoll, A., Spring, A., \& Kerrigan, S. (2001). Assessing servicelearning and civic engagement: Principles and techniques. Providence, RI: Campus Compact. Gray, M. J., et al. (1999). Combining service and learning in higher education evaluation of the learn and serve America, Higher education program. Santa Monica, CA: The RAND Corporation. (ERIC Document Reproduction Service No. ED430495).

Hammack, D. C. (Ed.). (1998). Making the nonprofit sector in the United States: A reader. Bloomington, IN: Indiana University Press.

Harkavy, I., \& Puckett, J. L. (1994). Lessons from Hull House for the contemporary urban university. Social Science Review, 68, 299-321.

Jameson, J. K., Clayton, P. H., \& Bringle, R. G. (2008). Investigating student learning within and across linked service-learning courses. In M. A. Bowdon, S. H. Billig, \& B. A. Holland (Eds.), 
Advances in service-learning research: Scholarship for sustaining service-learning and civic engagement (pp. 3-27). Greenwich, CN: Information Age Publishing.

Kendrick, J. R. (1996). Outcomes of service-learning in an introduction to sociology course. Michigan Journal of Community Service Learning, 3, 72-81.

Langseth, M., \& Plater, W. M. (Eds.). (2004). Public work and the academy: An academic administrator's guide to civic engagement and service-learning. Bolton, MA: Anker.

Levine, P. (2003, November). Service-learning research and the movement for youth civic engagement. Keynote address at the 3rd annual international service-learning research conference, Salt Lake City, UT.

Marchese, T. J. (1997). The new conversations about learning: Insights from neuroscience and anthropology, cognitive studies and work-place studies. In Assessing impact: Evidence and action (pp. 79-95). Washington, DC: American Association for Higher Education.

Markus, G. B., Howard, J. P. F., \& King, D. C. (1993). Integrating community service and classroom instruction enhances learning: Results from an experiment. Educational Evaluation and Policy Analysis, 15, 410-419.

Moely, B. E., Mercer, S. H., Ilustre, V., Miron, D., \& McFarland, M. (2002). Psychometric properties and correlates of the Civic Attitudes and Skills Questionnaire (CASQ): A measure of students' attitudes related to service-learning. Michigan Journal of Community Service Learning, $8(2), 15-26$.

Morton, K. (1995). The irony of service: Charity, project, and social change in service-learning. Michigan Journal of Community Service Learning, 2, 19-32.

Myers-Lipton, S. J. (1996). Effect of a comprehensive service-learning program on college students' level of modern racism. Michigan Journal of Community Service Learning, 3, 44-54. Nigro, G., \& Wortham, S. (1998). Service-learning through action-research partnerships. In R. G. Bringle \& D. K. Duffy (Eds.), With service in mind: Concepts and models for service learning in psychology (pp. 161-170). Washington, DC: American Association for Higher Education.

Osborne, R. E., Hammerich, S., \& Hensley, C. (1998). Student effects of service-learning: Tracking change across a semester. Michigan Journal of Community Service Learning, 5, 5-13. Plater, W. M., Jones, S. G., Bringle, R. G., \& Clayton, P. (in press). International servicelearning and the making of global citizens. In R. Lewin (Ed.), Study abroad and the making of global citizens. New York: Routledge.

Powell, W. W. (Ed.). (1987). The nonprofit sector: A research handbook. New Haven, CT: Yale University Press.

Reeb, R. N. (2006). The Community Service Self-Efficacy Scale: Further evidence of reliability and validity. Journal of Prevention and Intervention in the Community, 32(1), 97-113.

Reeb, R. N., Katsuyama, R. M., Sammon, J. A., \& Yoder, D. S. (1998). The Community Service Self-Efficacy Scale: Evidence of reliability, construct validity, and pragmatic utility. Michigan Journal of Community Service Learning, 5, 48-57.

Reeb, R. N., Sammon, J. A., \& Isackson, N. L. (1999). Clinical application of the servicelearning model in psychology: Evidence of educational and clinical benefits. Journal of Prevention and Intervention in the Community, 18(1), 65-82.

Sandy, M., \& Holland, B. (2006). Different worlds and common ground: Community partner perspectives on campus-community partnerships. Michigan Journal of Community Service Learning, 13(1), 30-43. 
Stage, A. A. (2000). Service-learning: Enhancing student learning outcomes in a college-level lecture course. Michigan Journal of Community Service Learning, 7, 5-13.

Steinke, P., \& Buresh, S. (2002). Cognitive outcomes of service-learning: Reviewing the past and glimpsing the future. Michigan Journal of Community Service Learning, 8, 5-14.

Sullivan, W. M. (1988). Calling or career: The tensions of modern professional life. In A. Flores (Ed.), Professional ideals (pp. 40-46). Belmont, CA: Wadsworth.

Sullivan, W. M. (2004). Can professionalism still be a viable ethic? The Good Society, 13(1), 15-20.

Sullivan, W. M. (2005). Work and integrity. The crisis and promise of professionalism in America. San Francisco: Jossey-Bass.

Tucker, M. L., \& McCarthy, A. M. (2001). Presentation self-efficacy: Increasing communication skills through service-learning. Journal of Managerial Issues, 13(2), 227-245.

Vogelgesang, L. J., \& Astin, A. W. (2000). Comparing the effects of community service and service-learning. Michigan Journal of Community Service Learning, 7, 25-34.

Wandersman, A., \& Florin, P. (1999). Citizen participation and community organizations. In J.

Rappaport \& E. Seidman (Eds.), Handbook of community psychology (pp. 247-272). New York: Kluwer/Plenum.

Warchal, J., \& Ruiz, A. (2004). The long-term effects of undergraduate service-learning paradigms on postgraduate employment choices, community engagement, and civic leadership. In M. Welch \& S. H. Billig (Eds.), New perspectives in service-learning: Research to advance the field (pp. 87-106). Greenwich, CT: Information Age.

Welch, M. (2007). Identifying and teaching civic engagement skills through service learning. In L. McIlrath \& I. M. Labhrainn (Eds.), Higher education and civic engagement: International perspectives (pp. 103-120). Aldershot, Hampshire, England: Ashgate.

Williams, N. R., King, M., \& Koob, J. J. (2002). Social work students go to camp: The effects of service learning on perceived self-efficacy. Journal of Teaching in Social Work, 22(3/4), 55-70. Zimmerman, M. A., \& Rappaport, J. (1988). Citizen participation, perceived control, and psychological empowerment. American Journal of Community Psychology, 16, 725-750. Zlotkowski, H. (1999). Pedagogy and engagement. In R. G. Bringle, R. Games, \& E. A. Malloy (Eds.), Colleges and universities as citizens (pp. 96-120). Boston: Allyn \& Bacon. 